\title{
Diverse Views of Political Empowerment Among Community College Students Who Receive Food Assistance Benefits
}

\author{
Adelaide K. Sandler ${ }^{1}$ D . Shannon R. Lane ${ }^{2}$
}

Accepted: 17 June 2021 /Published online: 24 June 2021

(c) The Author(s), under exclusive licence to Springer Nature Switzerland AG 2021

\begin{abstract}
This article examines political empowerment related to voting. The profession of social work requires practitioners to consider the social political roots of problems and to work to remediate them through micro and macro interventions, informed by political empowerment. Political empowerment involves having the power, ability, critical awareness, and sense of group identity to take action in order to create change in a political system. Findings from a qualitative study are presented to explore how recipients of food assistance benefits, enrolled in community college make decisions about voting. Data collected provides rich and contextual insight into how the decision to vote or not vote corresponds with an academic understanding of political empowerment and suggests that choosing not to vote may represent a type of political empowerment. Social work interventions related to voting for this population could include reducing stigma around government assistance, voter engagement, and work with systems to recognize the political power of those who are often left out of the process.
\end{abstract}

Keywords Political empowerment $\cdot$ Voting $\cdot$ Alienation $\cdot$ Self-efficacy $\cdot$ Social work

\section{Introduction}

Since the beginnings of the social work profession, unequal distribution of power has impacted vulnerable populations and shaped the focus of social work (Reisch, 2019). Through her work at Hull-House, Jane Addams viewed poverty as a consequence of economic, social, and political structures, not individual deficits (Gutierrez \& Lewis, 1999). Likewise, Bertha Reynolds recognized the structural

Adelaide K. Sandler

adelaide.sandler@marist.edu

1 School of Social and Behavioral Sciences, Marist College, Poughkeepsie, USA

2 Wurzweiler School of Social Work, Yeshiva University, New York City, USA 
and institutional roots of problems that plagued individuals (Bandler, 1979). Ann Hartman (1993) declared "the profession of social work is political" (p. 365) and challenged the profession to take action to assist our clients in claiming their power within policy, agency, and interpersonal levels of structure. As this is written in 2020, we are living in a time of growing social and economic inequality, xenophobic ideology, and policies that are decided by partisan politics, all of which significantly affects the populations served by social work and reflect unequal distributions of power.

Unequal power arrangements are harmful to vulnerable individuals and communities. One example of a vulnerable group is recipients of means-tested government assistance through programs such as Supplemental Government Assistance Program (SNAP), Women, Infants, and Children (WIC), and Temporary Assistance for Needy Families (TANF), who are less likely to vote and participate in other political activities. As a result, they lose power to influence elected officials, who make policy (Verba et al., 1995). Research shows that economic inequality, social stratification, structures of domination, and racial ideologies lead to the vulnerability of communities that thwart their ability to respond to public crises (Zakour, 2019). Conversely, social, human, and political capital foster community resilience and function (Zakour, 2019). Now more than ever, the social work profession needs to understand and address the power differentials which maintain the status quo and perpetuates social and economic injustice (Reisch, 2019). This research attempts to address gaps in our understanding of political empowerment within our communities.

Political discourse surrounding social welfare policy and elections has the power to encourage or hinder voting (Campbell, 2007). The "American dream" promises equal opportunity and that hard work will lead to prosperity (Rank, Hirschl, \& Foster, 2014). The American dream frames success as achievement gained through efforts of an individual, not factors related to the social environment such as the economic market, job growth, opportunity for higher education, and social policy. Additionally, the American dream is predicated on the idea that all identity groups (race, ethnicity, gender, gender, sexual orientation, religion, and disability/ability) have the same opportunities from the starting line, which is untrue (Hutchison, 2019; Verba et al., 2003). Yet, "privilege, racism, sexism, anti-Semitism, heterosexism, classism, ableism, dominance, subortination, oppression, and patriarchy" (Johnson, 2006, p. 9) are embedded into every facet of our social system and limit equal opportunities for all people. According to Angelo McClain, NASW's CEO, "Racism sets up a hierarchical system where one group has more power and more resources" (Laurio, 2019, para. 5). Because it is perceived that everyone has equal opportunity for success, when success is not achieved, the individual or their parents are blamed (Rose, 1990; Ryan, 1971). These frames portray recipients of public assistance as lazy, immoral, and trying to take advantage of the system on the backs of hard-working Americans (Edin \& Shaefer, 2015; Wise, 2015). Images of recipients spending SNAP benefits on crab legs, mothers having more babies just to collect more welfare benefits, and the "pink-Cadillac-driving welfare queen" are frames used to shame and discredit recipients (Clawson \& Trice, 2000). Mainstream political narratives propagate the false policy myths that poverty is the exception that happens 
only to the undeserving, and that the design of welfare leads to dependency, laziness, and a culture of poverty (Winter, 2008; Wise, 2015).

These harmful stereotypes are compounded by systemic racism within the political and policy systems as well. Electoral systems are designed with deliberate structural barriers that suppress voter turnout of select populations and in turn influence elections (Leighley \& Nagler, 2014). Because these systems systematically discourage vulnerable populations from voting through the use of structural barriers and political tactics, politicians are encouraged to promote the policy interests of more powerful citizens (Piven $\&$ Cloward, 2000). Gerrymandering, voter ID laws, and restrictions of early voting disproportionately affect African Americans, Latinos, people living in poverty, and college students (Lieberman, 2012; Louthen, 2015). These and other restrictions have accelerated since the 2013 landmark Supreme Court decision Shelby $v$ Holder (McInerney et al., 2020). These types of political strategies and policies not only restrict voting by imposing legal barriers but also by perpetuating apathy and lack of political skills, which are internal barriers to voting (Piven \& Cloward, 2000).

\section{Theoretical Framework}

Empowerment is the guiding social work perspective used to address power differentials, in order to improve individual and community functioning and promote social justice (Gutierrez, 1994). Fundamentally, empowerment cannot be understood without acknowledging the personal is political, the role of power in social relationships, and that power is generated through social interaction (Almeleh et al., 1993; Leung, 2005). Gutierrez (1994, 1995) conceptualized empowerment as a linear process, requiring four psychological sub-processes: a sense of self-efficacy, development of critical consciousness, acquisition of skills, and involvement with similar others. Additionally, the development of critical consciousness includes three mutually reinforcing and necessary components: group identification, group consciousness, and self and collective efficacy (Gutierrez, 1995). Additionally, there are three levels of empowerment: (1) individual, which is related to a sense of personal control; (2) interpersonal, which requires an understanding of how social structures and social issues are related to the personal troubles of individuals; and (3) political, which relates to having the ability to influence structural changes to remedy personal troubles (Gutierrez, 1995; Zimmerman, 1995).

Carr (2003) expanded upon Gutiérrez's model of empowerment and Freire's (2012) understanding of conscientization, and postulated that empowerment is a "cyclical process of collective dialogue and social action that is meant to effect positive change" (p.18). In Carr's (2003) model, powerlessness is the starting position of empowerment, but transforms as individuals gain psychological power through the process of conscientization and political power from social action.

\section{Empowerment and Voting}

Within both the popular media and scholarly discussions about voting, a strong emphasis is placed on the idea that people are rational actors in their voting decisions. This school of thought is rooted in theories such as Ajzen and Fishbein's 
Theory of Reasoned Action (Fishbein, 2008), which suggests that people's intentions to act are a function of their beliefs that the behavior will lead to a specific outcome. This theory has been used for decades to predict concepts including condom use, coupon use, seat belt use, cheating, use of dental care, return to work after childbirth, and consumption of organic food (Scalco et al., 2017; Vallerand et al., 1992). Building from the Theory of Reasoned Action, Ajzen proposed the Theory of Planned Behavior, which suggests that individuals' perception of their own resources and opportunities will affect their feelings of control over their behavior (Madden et al., 1992).

Perception of control as a concept is most identified with Bandura's theories of self-efficacy. Bandura (1977) divided self-efficacy into people's understandings of their own ability to complete an action successfully, and their expectation that their successful completion of that act will result in the outcome they want. These concepts are described as internal and external political efficacy as used within political social work and political science literature (e.g., Ostrander et al., 2017).

Political empowerment involves having the power, ability, critical awareness, and sense of group identity to take action in order to create change in a political system. Having a sense of group identity and collective group interest is a critical component of political empowerment. The processes of individual and interactional empowerment are each essential to the development of political empowerment. Gutierrez' empowerment theory (1995) examines ways in which beliefs about the self "can contribute to individual, community, and social change" (p. 229) and that critical consciousness as described by Freire and others is a key component of these beliefs about self. Diemer \& Li (2011) found that increased critical consciousness is associated with the increased likelihood that marginalized youth will vote. They contend that "critical consciousness may be an under considered resource to facilitate marginalized youth's engagement in traditional political behavior, redressing racial/ethnic, socioeconomic, and generational disparities in political participation" (p. 1831). Sandler et al. (2020) suggest that informed voting, based on concepts related to critical consciousness, can increase the political power of populations served by social work.

Empowerment theory thus offers a more collectivist lens to interpret the individualistic perspectives of the wider culture. While many of these theories attempt to take account group membership (for example, by using race, class, or gender as control variables in analysis), critics note that these methods are unlikely to account for the presence of multiple identities, the subjective meaning of identities for individuals, and other variations in group identity in the real world (McClain et al., 2009) and that these measures work significantly better for African Americans than for other groups, particularly those who identify as White, Latinx, and Asian-American (Sanchez \& Vargas, 2016). Group consciousness is even more difficult to measure and compare across groups (McClain et al., 2009). McClain et al. also push back against the idea often perpetuated "individuals of the same group, ascribed or selfidentified, share common political goals and interests" (p. 481).

Empowerment theory is applied here not in opposition to the existing theories, but as a broader perspective. Through this lens, decisions about voting are not fully described by an individual's assessment of their own abilities to affect the system. 
Instead, we look at the voter's critical consciousness, specifically their understanding of their own group membership, and that group's status and access to power. These factors, difficult to quantitatively measure, can positively or negatively affect a person's feelings of individual and collective efficacy, and their subsequent actions.

\section{Literature Review}

Research affirms that the principles of empowerment theory are useful and necessary to guide micro and macro social work interventions to empower vulnerable populations. For example, when female union members engaged in legislative advocacy for equal pay their sense of having collective power increased (Almeleh et al., 1993). Additionally, their increased sense of political empowerment was the catalyst for them to gain self-worth and a critical understanding that their low pay was the result of discrimination, not a reflection of the importance of their work (Almeleh et al., 1993). This is consistent with Carr's (2003) suggestion that the principles of empowerment work as a cycle to reinforce one another. Gutierrez's (1995) research illustrates the impact and nature of consciousness in the empowerment process. Gutierrez found that Latino undergraduate students who participated in a consciousnessraising group, gained a sense of a linked-fate, understanding of structural failures, and knowledge about power relationships. Ultimately this led to their increased sense of consciousness, necessary for political empowerment. Parsons (2001) reported that women who were survivors of domestic violence or living in poverty gained empowerment through participation in a group with similar others. The context of learning in an environment of mutual relationship promoted their ability to gain confidence, develop knowledge and skills, learn advocacy skills, and take-action together to change policies (Parsons, 2001). These three examples illustrate real-world application of empowerment and illuminate understanding of the components related to empowerment.

In political science, Blais \& Rheault (2011) examined internal and external political efficacy and concluded that voters who have little information or interest in the political system can be motivated to see their vote as an effective part of the process if they have a general psychological inclination to believe it will be. Interested and informed voters rely less on their personal psychological inclinations and look for external evidence that their vote will make a difference. In their work, an individual's external political efficacy (or the belief that the system is responsive to their action) significantly predicts a person's belief that one's individual vote makes a difference. Research finds that African Americans and Latinx populations have a lower sense of external efficacy than White European populations, which can be explained by the government being less likely to respond to their policy needs (Kahne \& Westheimer, 2006). Likewise, Hope \& Jagers (2014) found that external efficacy is a predictor of political engagement and that political cynicism decreased political engagement in Black youth. Ostrander et al. (2017) found that increases in internal, external, and overall efficacy correlated positively with participants' plans to engage in future political activities, including voting. Interestingly, in youth from households receiving means-tested assistance, internal efficacy is less likely to 
predict political participation than youth in households not receiving means-tested assistance (Barnes \& Hope, 2017).

People living in poverty are less likely to vote because of structural barriers hindering their ability to get to the polls, apathy (Piven \& Cloward, 2000), and their belief that politicians neither care nor address social issues relevant to them (Blau, 2014). Recipients may feel "less than" and invisible to politicians because of their treatment by those who administer government assistance, the stigma related to being a recipient of means-tested assistance, and their lived experiences with an inadequate government safety net to provide for their basic needs. (Abramovitz, 2014; Trattner, 1999). Those in need are stigmatized by the often punitive, time-consuming, and dehumanizing process to prove their eligibility (Edin \& Schaefer, 2015; Swartz, Blackstone, Uggen \& McLaughlin, 2009; Trattner, 1999). As a result, recipients of means-tested assistance are significantly less likely to vote than non-means-tested recipients (beyond differences in socioeconomic status and educational level), which creates political inequality (Swartz, Blackstone, Uggen \& McLaughlin, 2009). Significantly, the time, energy, and ability to get to the polls can be significant barriers (Edin \& Schaeffer, 2015; Soss \& Schram, 2007). Yet many marginalized citizens overcome alienation and vote. Statistical data and analysis have not discerned withingroup differences between those recipients of means-tested assistance who vote and those who do not vote.

\section{Research Question}

The research question answered within this study is "What evidence of political empowerment related to voting is found within community college students who are recipients of food assistance, through Supplemental Government Assistance Program (SNAP) and/or Women, Infants, and Children (WIC)?”.

\section{Methodology}

This study was part of a larger qualitative project which asked community college students who were recipients of means-tested government assistance how they make decisions about voting. IRB approval was received from the first author's doctoral institution and three community colleges in a northeastern state. With permission and cooperation of the Behavioral and Social Science Department Chairs of each college, the researcher contacted professors who taught introductory-level psychology, sociology, and human services classes to make classroom recruitment presentations and distribute and collect eligibility/interest forms. During presentations, the researcher explained the study and eligibility requirements and that as a thank-you participants would receive a $\$ 15$ grocery store gift card after the completion of the semi-structured interview. The identity of those who participated in the study was kept confidential, and no participant received extra-credit for their participation.

The researcher met with each participant to explain the study, complete the informed consent process, and collect demographic data and voting histories. At a second meeting, a one-on-one semi-structured interview was conducted using 
an interview guide. Each interview was audiotaped, transcribed, and uploaded to NVivo10 for coding and analysis. Coding was conducted by a co-author and another researcher, and inter-coder reliability was determined through NVivo's coding comparison feature. A grounded theory approach was used to analyze data from which knowledge emerged about how recipients make decisions about voting.

\section{Results}

\section{Sample}

Twenty-eight participants were recruited. The sample was almost evenly distributed between the three community colleges where recruitment took place. The most critical characteristic for this study was the status of voter or nonvoter. There were slightly more participants who previously voted in any election than those who had never voted in any election: sixteen previously voted (54\%) while twelve had never voted (46\%). All but one participant (96\%) received SNAP benefits. Of those who received SNAP, two participants also received WIC benefits, and one received TANF and WIC benefits. One participant (4\%) received only WIC benefits. The sample reflected diversity of racial and ethnic backgrounds. Just less than half (46\%) of the sample, thirteen participants, identified as Non-Hispanic White. Eight participants (29\%) identified themselves as being Black/African American, five participants (18\%) as Puerto Rican, five (18\%) as Hispanic/Latino, and two participants (7\%) as Bi-racial or Multiracial. Five participants identified themselves with multiple demographic categories.

Participants ranged in age from 21 to 46 years old, and the average age was 28. The sample included almost twice as many women than men. Of the twentyeight participants, nineteen $(67.86 \%)$ identified as female, eight $(28.50 \%)$ identified as male, and one (3.57\%) as transgender. Over one-third (39.29\%) of the sample, eleven participants, were pre-social work/human services majors. The majors of the seventeen other participants included general studies/liberal arts/undecided (4 participants), medical assisting/pre-nursing (4 participants), criminal justice (3 participants), biomolecular engineering, business administration, computer science, physical therapy, music, and teaching. Sixteen participants $(57.14 \%)$ had a student loan. Participants resided in urban, suburban, and rural communities in the northeastern state.

The participants had an array of life experiences. The following data is not discussed in reference to other traits of participants so that their identities are protected. Three $(10.71 \%$ ) participants were veterans of the conflict in Afghanistan. Two participants self-disclosed being homeless for several months in the past 2 years. Eighteen $(65.26 \%)$ of the participants reported being single or never married. Seven $(25 \%)$ participants identified as being married or living together; two of these participants are married to each other. Three participants (10.71\%) were divorced or separated, one of whom disclosed getting married just to get health insurance in order to have surgery and then divorced immediately after. Thirteen $(46.43 \%)$ participants were parents, and four self-disclosed during the qualitative interview that they struggled 
being a single parent. One participant grew up in the foster care system. See Table 1 for a list of demographic traits of each participant.

\section{Findings}

The data presented is part of a larger study of the political attitudes of the participants (Sandler, in press). This article reports the findings of the research related to political empowerment. The qualitative approach provided the framework to truly unpack motivations for voting behavior. Four distinct voter types emerged: dedicated voters, voters, nonvoters, and dedicated nonvoters. Dedicated voters and dedicated nonvoters adopted strong voter or nonvoter schemas. Both dedicated voters and

Table 1 Overview of participants

\begin{tabular}{|c|c|c|c|c|c|}
\hline Pseudonym & Voted & Assistance & Age & Major & Ethnicity/Race \\
\hline Daniel & Yes & SNAP & 29 & Business & Non-Hispanic White \\
\hline Raven & Yes & SNAP & 37 & Nursing & Black \\
\hline Jason & Yes & SNAP & 22 & General Studies & Puerto Rican \\
\hline Jasmine & Yes & SNAP & 28 & Nursing & Black \\
\hline Tyra & Yes & SNAP & 34 & Human Services & Black \\
\hline Peyton & Yes & SNAP & 27 & Human Services & Black \\
\hline Carlie & Yes & SNAP & 32 & Human Services & Non-Hispanic White \\
\hline Bradley & Yes & SNAP & 25 & Music & Black \\
\hline Brittany & Yes & SNAP & 28 & Teaching & Non-Hispanic White \\
\hline Mike & Yes & SNAP & 39 & Medical Assisting & Non-Hispanic White \\
\hline Jada & Yes & SNAP/WIC & 27 & Human Services & $\mathrm{Bi} / \mathrm{Black}$ \\
\hline Suzie & Yes & SNAP & 28 & Human Services & Non-Hispanic White \\
\hline Melanie & Yes & SNAP & 46 & Nursing & Non-Hispanic White \\
\hline Shanice & Yes & SNAP & 23 & Human Services & Black \\
\hline Jose & Yes & WIC & 27 & General Studies & Hispanic/Puerto Rican \\
\hline Winter & Yes & SNAP/WIC/TANF & 26 & Human Services & Hispanic/Puerto Rican \\
\hline Donna & Never & SNAP & 21 & Criminal Justice & Hispanic/Puerto Rican \\
\hline Christine & Never & SNAP & 22 & Physical Therapy & Non-Hispanic White \\
\hline Brandy & Never & SNAP & 28 & Liberal Arts & Non-Hispanic White \\
\hline Stacy & Never & SNAP & 35 & Human Services & Non-Hispanic White \\
\hline Sandy & Never & SNAP & 21 & Criminal Justice & Non-Hispanic White \\
\hline Pat & Never & SNAP & 23 & Undecided & Puerto Rican \\
\hline Daryl & Never & SNAP & 23 & Human Services & Black \\
\hline Sam & Never & SNAP & 29 & Computer Science & Non-Hispanic White \\
\hline Joy & Never & SNAP & 28 & Criminal Justice & Hispanic/White \\
\hline Alexus & Never & SNAP & 22 & Human Services & Hispanic/Black \\
\hline Sarah & Never & SNAP/WIC & 24 & Human Services & Non-Hispanic White \\
\hline Franklin & Never & SNAP & 25 & Bio. Engineering & Hispanic/Biracial \\
\hline
\end{tabular}

Data linking community colleges to participants is not included to protect the identities of participants. Yes $=$ voted in any past election; Never $=$ never voted in any election 
dedicated nonvoters conveyed critical awareness about how government and elections impact their lives and the direct relationship between politics and welfare policy. Dedicated nonvoters perceived democracy as not possible, and therefore believe government policy would never reflect their needs, so they chose not to vote. Voters and nonvoters described less critical awareness about how elections impacted their lives, little political knowledge, and did not recognize the connection between politics and social welfare policy. Their decision to vote or not vote often was influenced by the connection they felt with a candidate, social networks, structural barriers, and convenience. Many voters described little to no critical awareness, all nonvoters lacked critical awareness, while both dedicated voters and dedicated nonvoters expressed significant critical awareness. It is important to note that none of the participants had ever been contacted by a campaign in any way or asked to vote. This is true even of those who are dedicated voters, who might have been expected to have contact with campaigns or elected officials. These findings suggest that each of the four voter types makes decisions about voting for varying reasons, and each displays different components of empowerment. Here, we discuss the findings as they related to political empowerment.

\section{Findings Related to Political Empowerment}

Politically empowered actions reflect critical awareness and are intended to effect change. This section focuses on how, if at all, each voter type made voting decisions with respect to potential collective group interests of recipients of food assistance. It reviews findings about the ways voting decisions represent political empowerment.

Dedicated voters always vote because they believe the action of casting a ballot is in their self-interest. In thinking about the four necessary sub-processes of empowerment as delineated by Gutiérrez (1995), dedicated voters have self-efficacy, critical consciousness, and skills needed to vote. As demonstrated by the following statement by Melanie, a 46-year-old non-Hispanic/White female, dedicated voters have a collective sense of "we," "I think it is very important because we need to take control as much control as we can of who is running the government." However, they do not necessarily have a sense of linked fate with other recipients of means-tested assistance. Some had suspicions about others who receive means-tested government assistance and accepted stereotypes of welfare recipients being "cheaters." For example Tyra, a 34-year-old African American female is misinformed about federal limits on cash assistance and believed recipients prefer to stay home rather than go to work. From this belief, she connected that she is adversely impacted because others are cheating the system:

Just the government can impact a lot for like SNAPS, food stamps, um the welfare, like I wish they would do something about that. Because here you get the two years, and then they make you go off and work. But there are some states where you could stay on cash assistance for the rest of your life. And that do not help us or the country by doing that. Because they are comfortable with their situation. They get cash assistance. They would never leave their houses and go to work. And that impacts us a lot. 
Raven, a 37-year-old African American female also referred to others cheating the system: "There is a lot of people that are on SNAP who do not need it. They do not need to be on SNAP. They are really cheating the system."

Even though Tyra and Raven were critically aware about the relationship between electoral politics and their lives, they were not immune from the pervasive hegemonic narratives about recipients of food assistance and welfare, which kept them from identifying with other recipients. They blamed other recipients, whom they perceived to be less "needy" or "worthy" of benefits, for taking benefits away from them. In light of perceived social norms related to capitalism such as the promise of the American dream, competition, and a focus on the individual instead of the collective, their opinions are understandable. Their desire to limit the eligibility for social welfare programs seems to relate to inherent competition between recipients, which alienates them from one another. In consideration of political empowerment, the inability of some dedicated voters to identify with others who receive benefits limited their ability to be fully politically empowered. They did not make voting decisions based on the interests of the collective because they did not recognize their shared group identity with other recipients.

Other dedicated voters did not accept these frames. Brittany, a 28 -year-old non-Hispanic/White female had a sense of linked fate with other recipients, whom she described as "not having fun" living on government assistance. She also suggested the voting habits of recipients contribute to the continued flawed social welfare system:

When you look at the numbers there are actually very few people taking advantage of the welfare system. They are very few people who are you know living off this [welfare benefits] for funzies, and most of the time it is out of necessity. It's out of, this is a smart decision to actually support myself and my family. I don't have any other options. And like I said you have this cyclical thing that keeps happening...the system is keeping people trapped. And oftentimes the way that they [recipients] are voting and the candidates that they are voting for, are contributing to that system design and the way that it is keeping people trapped.

Likewise, Jada, a 27-year-old biracial/Black female, voted to represent the underdog, demonstrating her strong connection to others like her. When asked whether her past or current enrollment in governmental programs affected her views on politics or voting, she said.

Yes...Because it goes back to the government taking care of their citizens. You know? Some people are not fortunate, we do not live in a perfect society where everyone can just get up and be on their feet. You know? Or if they have not inherited wealth or class, they are kind of stuck you know? So that makes me want to vote, because I feel like um I am representing them you know, the under-dog. 
Dedicated voters, like Brittany and Jada, who have solidarity with other recipients and recognized their shared interests are politically empowered. Their opinions and nature were in sharp contrast to other voters.

Voters had less critical awareness about the impact of socio-political factors on their lives and less recognition about how politics affects social welfare policy than did dedicated voters. Most did not make decisions about voting based on their selfinterest of being recipients of food assistance because they did not see the connection between the two. Some identified having a class interest, which demonstrated having connection with similar others. This is consistent with the undefined collective sense of "we" felt by dedicated nonvoters. For example, Mike, a 39-yearold non-Hispanic/White male, associated the importance of how he votes with his socioeconomic status: "I think it's extremely important, especially...well at least for me maybe it's just because of where I stand socioeconomically." Still, despite this connection to his socioeconomic status, Mike does not appear to feel linked to other recipients of means-tested assistance. In the following quote, notice how he refers to himself as using government assistance "how it is supposed to be used," which assumes other recipients do not use it in this way. "I rely on that [SNAP] right now. I've been on it. I've come off of it. I use it how it's supposed to be used." He, like other voters, did not have a sense of group identity with other means-tested recipients because of his acceptance of hegemonic frames related to means-tested government assistance.

Some voters did not understand the connections between electoral politics and their government assistance. When asked by the researcher, "How does your past or present enrollment in government programs like SNAP change your view about politics or affect your view about politics and voting?" Winter, a 26-year-old Hispanic/ Puerto Rican female, replied, “It don't affect my voting, cause my voting's just my voting, you know?" Other voters discussed that even though they voted, they never thought voting was important because they never considered there was a connection between electoral policies and their lives. Shanice, a 23-year-old African American female explained that her human services class gave her knowledge about this connection and referred to her past voting as being "random:"

Honestly, before I took this class [human services] I had no idea about any of this and how much the government has done and anything. This class has opened my eyes to so much, say the child welfare, the social welfare, the Social Security act, the Medicaid, Medicare everything all the programs the government has on... Say if I voted next year knowing all the information I know this year, I would choose specifically more carefully than just say randomly selecting just a person and a party that I feel would do a good job.

Nonvoters are disinterested in politics, apathetic about voting, and believe elections do not affect them. Nonvoters had no understanding of how electoral politics affected their lives and did not care that it might. When the researcher asked Franklin, a 25-year-old Hispanic/Bi-racial male, how he considered politics or government to be relevant to his life, he could not think of anything, "I am not sure, I have never really thought of that... I just don't see a connection between politics and being a regular citizen." Therefore, not only did he not understand the connection between 
elections and his government assistance, as in the case of some voters, he also did not see a connection between government and his life. Franklin was not alone in this lack of understanding. As Donna, a 21-year-old Hispanic/Puerto Rican female, stated, "I think for now it is irrelevant. I am just a student."

These core beliefs may hinder their ability to recognize how their group and selfinterests are related to voting. They do not describe a sense of individual or interactional empowerment necessary for political empowerment. If they are aware of these things, they still do not vote but are not sure why they do not vote. Stacy, a 35-year-old non-Hispanic/White female, explained she does not know why she does not vote:“It's not like I'm bitter or... I just don't vote. (laughs) As I'm talking to you I'm realizing that I probably should [vote] but I just don't. Like I never have and I'm not sure why." The decision making of nonvoters is not politically empowered.

Dedicated nonvoters, as opposed to nonvoters, were not apathetic. They paid close attention to how the government impacted their daily lives and were angry and resentful about its negative control over them. They strongly felt politicians did not care about their needs and never will care about them. They lacked trust in democracy, elected officials, and the government. This is their truth based on their lived experiences, including receiving means-tested assistance. For example, notice how Brandy, a 28-year-old non-Hispanic/White female, conveyed critical awareness about how the social structure impacts her life and perceived that politicians lacked this awareness and assumed poverty is the result of individual failures, not structural ones. (Note: She is responding to the questions, "Does being a recipient of SNAP affect your views about politics or voting?").

I think a lot of politicians... are saying minimum wage jobs are starting points and they are for like teenagers, or for you know people who still live at home. And it is like, that is not the case. I graduated from high school, I don't have a record and I worked a minimum wage job for three years. Just because I couldn't find anything better... I wanted to come here [community college]... I had my older son when I was 16 , so I needed a babysitter, so these people have this attitude like (makes a face)... It's like politicians in general, think like people, who work at minimum wage jobs are there because they want to be there, or they don't have goals, or they don't do anything or they abuse the system. So it's like yea...everybody has this idea of the American dream and that anything is possible but it is really not that easy.

Dedicated nonvoters demonstrated critical awareness about how they are impacted by politicians and government policy. In the following passage, consider how Alexus, a 22-year-old Hispanic/Black female, explained that electoral politics directly affects her SNAP benefits, college costs, and healthcare, but even so she decided not to vote:

I receive food stamps so I know it does affect somehow, not all the time, but it does affect how much I receive and that affects my family and how much I can eat and how much my family can eat. So I understand that aspect to it. It can affect how much I receive in financial aid, um, from, to go to school, to go to college, how much I can receive in grants or scholarships. So I know it 
affects that aspect of my life and it affects my community... So I know the voting can change things, because different candidates can have different views on the way money for education can be distributed...and the money for food stamps and for governmental programs also are affected. Like I receive state health care, it's free for me to have healthcare, but it can always change. So I understand that aspect of it.

Clearly, Alexus is not apathetic and exhibited critical awareness about the government's influence on her life.

Dedicated nonvoters seem to feel an overwhelming sense of powerlessness, helplessness, and alienation which limited individual empowerment (Zimmerman, 1995). These strong feelings suggest that objectors have internalized their own oppression. Members of this group also expressed knowledge of the transactional nature of the person:environment relationship and how electoral politics and government policy influenced their lives, which suggested they had interactional empowerment. Additionally, dedicated nonvoters suggested a shared sense of group identity with other recipients, and did not feel alienated from them nor in competition with them. Instead, they blamed their problems on the government, not other recipients. Daryl, 23-year-old African American male, described this competition as being like "crabs in a bucket."

And where I am from, I feel like it is like crabs in a bucket. Like, I gotta push you down for me to come up and not really build it together to like make a goal. It's like push, push, push. I gotta get out for me.

Consider the following two excerpts from participants, who are both human service majors, but one is a voter and one is a dedicated nonvoter, about their perceptions regarding social welfare policy. Notice where each participant places "blame" for not receiving enough SNAP benefits to feed their families:

It's like 'dag' that's the only help you're giving me? Like you know like they're really trying to like, 'oh yeah live off of a hundred dollars, a hundred and fifty dollars of food stamps' like you know? Like that's literally not enough to feed a family but then again some people get it who do not need it.

Versus:

I don't like the government. I don't want them to have so much control over, um, how much aid I receive to go to school because I can't take as much classes as I want to. I feel like I don't get enough to feed the people in my household or myself.

The first statement by Winter, a voter who is a 26 -year-old Hispanic/Puerto Rican female, blames other recipients, who do not really "need" benefits, for her family not having enough food to eat. The second statement by Alexus, a dedicated nonvoter who is a 22-year-old and Hispanic/Black, blames the government for not giving her more SNAP benefits so her family can eat.

Additionally, dedicated nonvoters blamed themselves less for their situations and their need for government assistance. Consider how Jose and Sam, both veterans, 
thought about their benefits. Jose, a voter who is a 27 -year-old Hispanic/Puerto Rican male, is grateful for WIC:

Like the past couple years we had, my wife and I had WIC since we had our son and in the military, as a low ranking person you don't really make much, uh, much money (laughs), and, uh, so that extra couple gallons of milk, cheese, and bread is a big difference. Um, you know, especially when you're working with two, three hundred bucks for groceries for your entire month, that can uh, that can help subsidize some of that lack of.

Jose accepted that his position in the military does not provide enough income to feed his family. He does expect a living income as a "low ranking person" in the military. On the other hand, Sam, a dedicated nonvoter also in the military, viewed his need for SNAP completely differently:

I kind of feel and this goes back to the military. I kind of feel that you know, like being in the military, now coming home, for me to have to resort to getting SNAP is kind of a proof, that you know a soldier that fights for this country and puts the time and effort in now has to result to getting help and not being able to survive and struggling every day when we shouldn't have to do that.

Clearly dedicated nonvoters demonstrated critical awareness and shared group identity, but they did not show self-efficacy. The coding matrix of codes related to shame, stigma, and group identification clearly shows that dedicated nonvoters had the most codes associated with a group identity and the least coding associated with shame and stigma. This is a defining feature of the dedicated nonvoter type. Dedicated voters and voters had more coding related to shame and stigma than dedicated nonvoters and nonvoters. It is important to note that dedicated nonvoters only had one code related to shame and stigma and the most codes related to group identification, despite the fact they are numerically the smallest voter type. This emphasizes the strength of connectedness felt by dedicated nonvoters to other recipients. It also distinguishes them from other voter types. This is a significant finding. Dedicated nonvoters were the only voter type to have no sense of individual empowerment, have a strong sense of resignation, alienation, and have the greatest sense of group identity. These distinctions are important to consider in relationship to understanding the definition of political empowerment. Based on these findings, should the voting decisions of voters like Winter be considered politically empowered because they act by casting a ballot? Conversely, should the voting decisions of dedicated nonvoters like Alexus be considered politically empowered because they have critical awareness and a group identity with other recipients, or not empowered because they do not act and do not cast a ballot?

\section{Discussion}

The findings of this research provide insight into voting decisions, the profession of social work, and ways to increase voter turnout of marginalized citizens. These results suggest that in order to address the lack of political power held by recipients 
of means-tested assistance, indirect interventions are needed to encourage recipients to gain understanding about the political process, think more critically about the importance of voting, acquire a sense of a group identity with other recipients, and consider voting decisions in strategic ways.

Empowerment should be considered within the context of each individual's lived experiences and with deference to preserving the self-determination of all people. Knowledge gained from this research suggests that some voters are not politically aware or empowered, and some nonvoters are very politically aware and empowered. Dedicated nonvoters appear critically aware; they know how the government affects their lives and they do not feel as much shame or stigma about means-tested assistance as other voter types. The decision not to vote by dedicated nonvoters serves a purpose for them. Their inaction is resistance. Dedicated nonvoters were keenly aware that it was Election Day, knew where and how to cast a ballot, had knowledge about the candidates' positions, understood the relationship between politics and their government assistance and/or lack of assistance, and they chose not to vote. One dedicated voter reported that he took his grandmother to the polls to vote and stood outside while she cast her ballot. Dedicated voters refuse to be part of a system that ignores their needs and contributes to their marginalization. They express alienation from the government's lack of response to their needs and resignation that there is nothing they can do to change that, not even cast a ballot on Election Day. Kahne \& Westheimer (2006) contend that when working with populations for whom government is less responsive, the appropriate action is to work to increase government responsiveness.

In understanding the nature of empowerment, a conundrum exists in the case of dedicated nonvoters. While their decision not to vote is meant to convey their lack of trust in the system and discontent with the status quo, some political elites interpret nonvoting as satisfaction with the status quo or lack of having any political opinion. Therefore, their decision not to vote may actually harm their group's ability to improve their socioeconomic conditions. The findings of this study call into question whether all the sub-processes of empowerment (Gutiérrez, 1995) are equally important and how social workers can identify and understand political empowerment. More research is needed on differentiating the sub-processes of empowerment and on further developing the concept of political empowerment in order to guide evidence-based social work practice.

The findings may be considered in relation to the concepts of internalized oppression and alienation. Internalized oppression is the acceptance of the dominant group's beliefs, attitudes, values, and goals, in part, as a result of political frames and discourse. Oppression is actually injustice caused by structural forces and transmitted through social institutions, media, schools, welfare offices, and average citizens in everyday situations until it is internalized in our collective consciousness (Rose, 1990; Young, 2008). According to Brazilian philosopher and educator Paulo Freire (2012) known to have developed the concept of conscientization, oppressed populations accept the status quo of their existence because they accept the "truths" of the elite and internalize their own oppression, which stop the masses from acting in their self-interest. In this way, elite framing and political discourse are used as social control. Recipients of means-tested assistance suffer from the self-imposed 
shame of getting government assistance (Edin \& Shaefer, 2015). They often have "disdain" for welfare, lack sympathy for other recipients, and suffer from the stigma of others (Hirschl, Rank \& Kussi-Appouch, 2011; Rank, 1994). All voting types, except the dedicated nonvoter, included voters who demonstrated this lack of sympathy for others recipients of government assistance.

Many recipients appear to internalize elite framing of poverty and governmental assistance, which may prohibit their ability to share a collective group identity with similar others and take action to protect their interests. This internalization affects how recipients interpret policy positions of elected leaders and make decisions about voting. In this way, the participants in this study are similar to voters from other demographic groups, in that decisions about voting are connected to emotion as much as critical thinking.

Alienation is defined by the Social Work Dictionary (2014) as "the feeling of apartness or strangeness experienced in cultural or social settings that seem unfamiliar, unacceptable, or unpredictable" (Barker, 2014, p.15). Alienation is associated with the loss of control over a situation and shapes a person's identity, life experiences, and the development of consciousness (Ferguson \& Lavalette, 2004). Additionally, those without access to work are further controlled by the policing of welfare agencies and presence of stigma (Ferguson \& Lavalette, 2004). Melvin Seeman, who wrote the seminal article "On the Meaning of Alienation" in 1959, thought alienation "bridged the social and the psychological" (Anderson et al., 2016, p. 200). In this way, alienation is conceptualized as a psychological state and result of the social structure, which affects individuals according to their social location (Ferguson \& Lavalette, 2004). In terms of how a citizen feels in relation to a political system, alienation is a sense of being outside and forgotten by the system which surfaces as hostility towards politics/government, feelings of betrayal by leaders, and/or conviction that politicians are liars (Henslin, 2011). Alienation from politics stems from the consensus that average Americans "don't have much say in what the government does" and that "government is run by a few big interests" (Blau, 2014, p.126). Those who feel powerless perceive they lack resources or ability to be independent and influence others in their environment (Barker, 2014), and they are less likely to vote. Clearly, dedicated nonvoters feel alienated and powerless and from their perspective and social location, not voting is a rational and empowered decision for them.

\section{Limitations}

Limitations of this study include the political context in which it was conducted. This study was conducted during the 2016 presidential contest, a particularly active and politically divisive moment, in a relatively liberal Northeastern state. Since the data collection occurred, the COVID-19 pandemic and the 2020 election have created significant change for residents of the United States, and may have caused significant changes in the lives or perceptions of the study participants and others in similar situations. While this limits the generalizability of the information collected through this study, we hope this work lays the foundation for future work that highlights the experiences of community college students and those who are recipients of means-tested assistance. 
This study also included a small non-randomly selected sample, restricting its generalizability. The recipients may have been different in some way from other community college students or other recipients of means-tested benefits. Finally, participant answers may have been affected by social desirability bias in that participants might have emphasized what they thought the researcher, who disclosed she was studying voting, wanted to hear.

\section{Implications}

Social workers and social work educators are in the position to fight the pervasive perception that because politicians do not seem to care about the needs of marginalized citizens, they should not vote. This becomes a self-fulfilling, circular prophecy that reinforces the status quo. Both groups can play a powerful role in reducing this cycle by discussing this topic to trigger political interest and reframing the meaning of voting. They can also begin to break down the discrediting narrative about welfare recipients and causes of unemployment. This may encourage welfare recipients to be less alienated from one another and think of themselves as a collective. In regard to promoting informed voting, it is not a cliché to say that knowledge is power. For voter types, other than the dedicated nonvoter, increased knowledge about politics, how government works, governmental policies, and elections has the potential to contribute to informed voting decisions by community college students.

Social workers and social work students who participate in voter engagement activities such as those coordinated by the Nancy A. Humphreys Institute for Political Social Work at the University of Connecticut and the National Social Work Voter Mobilization Campaign (www.votingissocialwork.org) can use the results of this research to tailor their outreach and communication with college students, recipients of means-tested government assistance, and other marginalized groups. The results of this research suggest that those groups may benefit from more information about how policy affects their lives and the ways in which voting can express their political power.

In all research (social work, political science, sociology, and political polling), question wording is needed that distinguishes between apathy related to dedicated nonvoters and nonvoters. Polls such as the 2012 USA Today/Suffolk University Poll found that $41 \%$ of those planning not to vote had a belief that voting does not matter (Page, 2012). This does not distinguish between whether this belief is a product of apathy related to not caring or a product of alienation related to not believing democracy is possible. More nuanced question wording is needed to parse out these types of differences that have been illuminated in this study.

\section{Conclusion}

Ann Hartman (1993) astutely noted, "It may be that empowerment exists more in our professional discourse than in actual practice" (p. 365). The language of empowerment was a response to the limitations faced by clients to achieve self-determination: exploitation, oppression, inequality, and lack of opportunity; empowerment requires 
an active stance and "implies that people not only have the right to self-determination, but also the right to the power ability, and authority to achieve self-determination" (Hartman, 1993, p. 365). In order for change-oriented social work practice to occur, power must be understood and empowerment strategies need to be implemented in micro, mezzo, and macro settings (Almeleh et al., 1993; Fisher, 1995; Reisch, 2019). As we continue to explore issues related to understanding and measuring empowerment, it is important to remember that actions demonstrating empowerment might not look the same in every individual. The value of self-determination supersedes the goal of empowerment, as defined by scholars. This requires that social workers "meet the client" where they are in their understanding about the political system, their sense of self and group identity, and their interest in and perception of political power.

Acknowledgements We would like to thank our late mentor, Dr. Nancy A. Humphreys, for her guidance and support in the development of this research. We would also like to thank Maureen E. Clark for cocoding the transcripts and providing valuable insights.

\section{Declarations}

Conflict of Interest The authors declare no competing interests.

\section{References}

Almeleh, N., Soifer, S., Gottlieb, N., \& Gutierrez, L. (1993). Women's achievement of empowerment through activism in the workplace. Affilia, 8(1), 26-39.https://doi.org/10.1177/088610999300800103

Abramovitz, M. (2014). Definition and functions of social welfare policy. In J. Blau, The dynamics of social welfare policy (pp. 19-63). Oxford University Press.

Anderson, C., Turner, A. C., Heath, R. D., \& Payne, C. M. (2016). On the meaning of grit...and hope... and fate control....and alienation....and locus of control...and self-efficacy...and effort optimism....and. Urban Review, 48, 198-219. https://doi.org/10.1007/s11256-016-0351-3

Bandler, L. S. (1979). Bertha Capen Reynolds: Social worker of all times. Journal of Education for Social Work, 15(3), 5-12. https://doi.org/10.1080/00220612.1979.10671980

Bandura, A. (1977). Self-efficacy: Toward a unifying theory of behavioral change. Psychological Review, 84(2), 191-215. https://doi.org/10.1037/0033-295X.84.2.191

Barker, R. L. (2014). The social work dictionary (6th Ed.). NASW Press.

Barnes, C. Y., \& Hope, E. C. (2017). Means-tested public assistance programs and adolescent political socialization. Journal of Youth and Adolescence, 46, 1611-1621. https://doi.org/10.1007/ s10964-016-0624-X

Blais, A., \& Rheault, L. (2011). Optimists and skeptics: Why do people believe in the value of their single vote? Electoral Studies, 30(1), 77-82. https://doi.org/10.1016/j.electstud.2010.09.008

Blau, J. (2014). The dynamics of social welfare policy (4th ed.). Oxford University Press.

Campbell, A. L. (2007). Universalism, targeting, and participation. In J. Soss, J. S. Hacker, \& S. Mettler (Eds.), Remaking America: Democracy and public policy in an age of inequality (pp. 121-140). Russell Sage Foundation.

Carr, E. S. (Spring 2003). Rethinking empowerment theory using a feminist lens: the importance of process. Afflia, 18(1), 8-20. https://doi.org/10.1177/0886109902239092/

Clawson, R. A., \& Trice, R. (2000). Poverty as we know it: Media portrayals of the poor. The Public Opinion Quarterly, 64(1), 53-64. 
Diemer, M. A., \& Li, C. (November/December 2011). Critical consciousness development and political participation among marginalized youth. Child Development, 82(6), 1815-1833. https://doi. org/10.1111/j.1467-8624.2011.01650.x

Edin, K. J., \& Schaefer, H. L. (2015). \$2.00 a day: Living on almost nothing in America. Houghton Mifflin Harcourt.

Ferguson, I., \& Lavalette, M. (2004). Beyond power discourse: Alienation and social work. British Journal of Social Work, 34, 297-312. https://doi.org/10.1093/bjsw/bch039

Fishbein, M. (2008). Reasoned action, theory of. Wiley Publishing

Fisher, R. (1995). Political social work. Journal of Social Work Education, 31(2), 194-203. https:// doi.org/10.1080/10437797.1995.10672257

Freire, P. (2012). Pedagogy of the oppressed (30th Anniversary Ed.). Bloomsbury.

Gutierrez, L. M. (1994). Beyond coping: An empowerment perspective on stressful life events. Journal of Sociology and Social Welfare, 21(3), 201-220.

Gutierrez, L. M. (1995). Understanding the empowerment process: Does consciousness make a difference? Social Work Research, 19(4), 229-237. https://doi.org/10.1093/swr/19.4.229

Gutierrez, L. M., \& Lewis, E. A. (1999). Empowering women of color. Columbia University Press.

Hartman, A. (1993). Editorial: The professional is political. Social Work, 38(4), 365-366.

Henslin, J. (2011). Essentials of sociology (9th Ed.) Allyn \& Bacon.

Hutchison, E.D. (2019). Dimensions of human behavior (6th Ed.) Sage Publishing.

Hirshl, T., Rank, M., \& Kussi-Appouch, D. (2011). Ideology and the experience of poverty risk: Views about poverty within a focus group design. Journal of Poverty, 15, 350-370. https://doi. org/10.1080/10875549.2011.589680

Hope, E. C., \& Jagers, R. (2014). The role of sociopolitical attitudes and civic education in the civic engagement of Black youth. Journal of Research on Adolescence, 24(3), 460-470. https://doi. org/10.1111/jora.12117

Johnson, A.G. (2006). Privilege, power, and difference (2nd Ed.) McGraw-Hill.

Kahne, J., \& Westheimer, J. (2006). The limits of political efficacy: Educating citizens for a democratic society. PS: Political Science and Politics, 39(2), 289-296. https://doi.org/10.1017/ S1049096506060471

Laurio, A. (2019, August/September). Undoing racism: How the social work profession is working toward healing and equality. NASW. Retrieved from https://www.socialworkers.org/News/SocialWork-Advocates/2019-August-September/Undoing-Racism

Leighly, J. E., \& Nagler, J. (2014). Who votes now? Princeton University Press.

Leung, L. (2005). Empowering women in social work practice: A Hong Kong case. International Social Work, 48(4), 429-439. https://doi.org/10.1177/0020872805053467

Lieberman, D. (2012). Barriers to the ballot box: New restrictions underscore the need for voting laws enforcement. Human Rights, 39(1), 2-14.

Louthen, E. (2015). President Obama describes the need for structural electoral reform in NPR interview. FairVote.https://www.fairvote.org/president_obama_describes_the_need_for_structural_electoral_ reform_in_npr_interview

Madden, T. J., Ellen, P. S., \& Ajzen, I. (1992). A comparison of the theory of planned behavior and the theory of reasoned action. Personality and Social Psychology Bulletin, 18(1), 3-9. https:// doi.org/10.1177/0146167292181001

McClain, P. D., Johnson Carew, J. D., Walton, E., Jr., \& Watts, C. S. (2009). Group membership, group identity, and group consciousness: Measures of racial identity in American politics? Annual Review of Political Science, 12, 471-485. https://doi.org/10.1146/annurev.polisci.10. 072805.102452

McInerney, T. C., Thompson, K. Z., \& Shackelford, K. K. (2020). Alabama after Shelby v. Holder: Polling place changes and access to polling place information. Journal of Policy Practice and Research 1(4), 165-177. https://doi.org/10.1007/s42972-020-00018-7

Ostrander, J. A., Lane, S. R., McClendon, J., Hayes, C., \& Rhodes Smith, T. (2017). Collective power to create political change: Increasing the political efficacy and engagement of social workers. Journal of Policy Practice, 16(3), 261-275. https://doi.org/10.1080/15588742.2016.1266296

Page, S. (2012, August 15). Does every vote count? Why some Americans don't think so. USA Today. Retrieved from http://usatoday30.usatoday.com/news/politics/story/2012-08-15/non-voters-obamaromney/57055184/1

Parsons, R. J., \& (Summer, . (2001). Specific practice strategies for empowerment-based practice with women: A study of two groups. Affilia, 16(2), 159-179. https://doi.org/10.1177/08861090122094208 
Piven, F. F., \& Cloward, R. A. (2000). Why Americans still don't vote and why politicians want it that way. Beacon Press.

Rank, M. (1994). A view from the inside out: Recipients perceptions of welfare. Journal of Sociology and Social Work, 27(1), 27-47.

Rank, M. R., Hirschl, T. A., \& Foster, K. A. (2014). Chasing the American dream: Understanding what shapes our fortunes. Oxford University Press.

Reisch, M. (2019). Lessons from social work's history for a tumultuous era. Social Service Review, 93(4), 581-607. https://doi.org/10.1086/706741

Rose, S. M. (1990). Advocacy/empowerment: An approach to clinical practice for social work. Journal of Sociology and Social Welfare, 41, 41-51.

Ryan, W. (1971). Blaming the victim. Pantheon Books.

Sanchez, G. R., \& Vargas, E. D. (2016). Taking a closer look at group identity: The link between theory and measurement of group consciousness and linked fate. Political Research Quarterly, 69(1), 160174. https://doi.org/10.1177/1065912915624571

Sandler, A. K. (in press). Understanding how recipients of means-tested government assistance make the decision to vote or not to vote and how social workers can make a difference. Journal of Sociology and Social Welfare.

Sandler, A. K., Hylton, M. E., Ostrander, J., \& Smith, T. R. (2020). The three-legged stool of voter engagement. Critical Social Work, 21(2), 41-56. https://doi.org/10.22329/csw.v21i2.6463

Scalco, A., Noventa, S., Sartori, R., \& Ceschi, A. (2017). Predicting organic food consumption: A metaanalytic structural equation model based on the theory of planned behavior. Appetite, 112, 235-248. https://doi.org/10.1016/j.appet.2017.02.007

Soss, J., \& Schram, S. F. (2007). A public transformed? Welfare reform as policy feedback. In J. Soss (Ed.), Remaking America: Democracy and public policy in an age of inequality (pp. 99-118). Russell Sage Foundation.

Swartz, T. T., Blackstone, A., Uggen, C., \& McLaughlin, H. (2009). Welfare and citizenship: The effects of government assistance on young adults' civic participation. The Sociological Quarterly, Official Journal of the Midwest Sociological Society, 633-665.

Trattner, W. I. (1999). From poor law to welfare state: A history of social welfare in America (6th ed.). The Free Press.

Vallerand, R. J., Deshaies, P., Cuerrier, J. P., Pelletier, L. G., \& Mongeau, C. (1992). Ajzen and Fishbein's theory of reasoned action as applied to moral behavior: A confirmatory analysis. Journal of Personality and Social Psychology, 62(1), 98. https://doi.org/10.1037//0022-3514.62.1.98

Verba, S., Schlozman, K. L., \& Brady, H. E. (1995). Voice and inequality: Civic volunteerism in American politics. Harvard University Press.

Verba, S., Burns, N., \& Schlozman, K. L. (2003, Spring/Summer). Unequal at the starting line: Creating participatory inequalities across generations and among groups. The American Sociologist, 34(1/2), 45-69. https://doi.org/10.1007/s12108-003-1005-y

Winter, N. (2008). How ideas about race and gender shape public opinion. The University of Chicago Press.

Wise, T. (2015). Under the affluence: Shaming the poor, praising the rich and sacrificing the future of America. City Lights Books.

Young, I. M. (2008). Five faces of oppression. In J. DeFilippis, \& S. Saegert (Eds.), The Community Development Reader (pp. 276-285). Routledge/Taylor and Francis Group.

Zakour, M. J. Fall (2019). Macro-level interventions in disasters: Theoretical foundations for improving mental health outcomes. Best Practices in Mental Health, 15(2), 16-28.

Zimmerman, M. A. (1995). Psychological empowerment: Issues and illustrations. American Journal of Community Psychology, 23(5), 581-599. https://doi.org/10.1007/BF02506983 